\title{
Vulnerability and health promotion of Haitian immigrants: reflections based on Paulo Freire's dialogic praxis
}

\author{
Vulnerabilidade e promoção da saúde de imigrantes haitianos: \\ reflexões pela práxis dialógica de Paulo Freire \\ Vulnerabilidad y promoción de la salud de los inmigrantes haitianos: \\ reflexiones a través de la praxis dialógica de Paulo Freire
}

How to cite this article:

Souza JB, Heidemann ITSB, Walker F, Schleicher ML, Konrad AZ, Campagnoni JP. Vulnerability and health promotion of Haitian immigrants: reflections based on Paulo Freire's dialogic praxis. Rev Esc Enferm USP. 2021;55:e03728. doi: https://doi.org/10.1590/S1980-220X2020011403728

Jeane Barros de Souza ${ }^{1}$

Ivonete Teresinha Schulter Buss Heidemann ${ }^{2}$

\section{Fernanda Walker ${ }^{1}$}

Maira Lidia Schleicher ${ }^{1}$

Angélica Zanettini Konrad ${ }^{1}$

Juliana Praxedes Campagnoni ${ }^{3}$

${ }^{1}$ Universidade Federal da Fronteira Sul, Campus Chapecó, SC, Brazil.

${ }^{2}$ Universidade Federal de Santa

Catarina, Departamento de Enfermagem, Florianópolis, SC, Brazil.

${ }^{3}$ Universidade Federal de Santa Catarina, Programa de Pós-Graduacão em Saúde Coletiva, Florianópolis, SC, Brazil.

\section{ABSTRACT}

Objective: To understand the perceptions of Haitian immigrants about the possibilities to promote health, in the face of the vulnerabilities they experience. Method: This is a qualitative, participatory action study, based on Paulo Freire's Research Itinerary, which has three phases: thematic investigation; encoding and decoding; critical unveiling. Ten Haitian immigrants, students of a public university in Brazil, participated in the Culture Circle. Results: In the face of vulnerabilities, Haitian immigrants expressed the need to participate in university social groups, to have moments of integration with Brazilians, to know their rights, to master the Portuguese language, to adapt socially and culturally and to the food, to engage in the promotion of mental health and quality of life through physical activities and leisure. Conclusion: The discussions led to a process of actionreflection-action, in which immigrants reframed their reality, looking for strategies to promote health and empowering themselves in the search for a healthier life.

\section{DESCRIPTORS}

Immigration; Vulnerability; Health Promotion; Health Equity; Quality of Life; Public Health Nursing. 


\section{INTRODUCTION}

Migration flows in the world have become part of international policies for the protection of human rights. In Brazil, they have been present for decades, following the process of political and economic civilization. The subject has been debated in Brazilian policies, mainly due to the significant number of Haitian immigrants moving to the country, increased after the Brazilian government closed a deal with Haiti, the poorest nation in Latin America, granting them the humanitarian visa from $2012^{(1)} \mathrm{on}$.

In 2016, Brazil had 73,000 Haitians registered with the Federal Police, looking for employment, housing, protection of their rights, and decent living conditions. The Statute of the Foreigner (Law no. 6.815) is the Brazilian document that ensures them the same rights as the native citizens, including the right to a work permit, social security, and access to the Unified Health System (The Brazilian SUS). The Brazilian Federal Constitution of 1988 equally guarantees the rights to health, education, food, housing, work, leisure, and security for Brazilians and immigrants who have a visa. Nevertheless, there are difficulties in enforcing these rights, as many immigrants do not have a job or have worse conditions compared to those of Brazilians, resulting in low socioeconomic conditions ${ }^{(2)}$.

The law provides immigrants with the right to be attended by SUS. In general, they become ill due to difficulties in the new country, such as lack of income and homesickness, with biopsychosocial distress prevailing during adaptation ${ }^{(1)}$, which makes them vulnerable. Vulnerability is widespread, considered to be a reciprocal interdependence of multidimensional values; it limits the relational capacities of affirmation in the world, and this can generate fragility ${ }^{(3)}$.

Although they have a visa, Haitian immigrants have poor living, housing, and work conditions, and experience human rights violations, such as racism and xenophobia ${ }^{(1)}$. The difficulties of social integration, due to communication and local adaptation, contribute to their isolation ${ }^{(4)}$. Still, financial difficulties and those related to the separation from their native social circles combined with the lack of affective bonds in Brazil contribute to illnesses ${ }^{\left({ }^{(}\right)}$.

To improve this population's quality of life in Brazil, public policies aimed at the effective application of their rights are required; this would facilitate adaptation and reduction of vulnerabilities, with a view to promoting health ${ }^{(3)}$ that, in the Ottawa Charter for Health Promotion, is the process in which individuals are encouraged to control and improve their health ${ }^{(5)}$ with actions directed to the social determinants of health. When both are articulated and in conjunction with public policies, they can contribute to equity achievement ${ }^{(6)}$.

Thus, the research question emerged: what are the perceptions of Haitian immigrants about the possibilities to promote health, in the face of the vulnerabilities they experience? It is necessary to discuss with the immigrants themselves the possibilities to promote their health and disseminate their perceptions about quality of life to improve their assistance, consolidate the principles of SUS, and improve public policies in the sector, warranting this study. Then, the objective of the study is to understand the Haitian immigrants' perceptions about the possibilities to promote health in the face of the vulnerabilities they experience.

\section{METHOD}

\section{TYPE OF STUDY}

This is a qualitative, participatory action study ${ }^{(7)}$, based on the theoretical assumptions of Paulo Freire's Research Itinerary, which comprises three dialectically interconnected phases, namely: Thematic Research; Encoding and Decoding; and Critical Unveiling ${ }^{(8)}$. The Freirean Itinerary is developed in the Culture Circle, which is presented because of its possibility of helping individuals to understand their reality through their experience and share knowledge, in a space made up of different beings and practices. Thus, based on the libertarian pedagogical perspective, they take on the experience of the practice of dialogue in horizontal relationships, to discuss their problems and plan concrete actions of collective interest ${ }^{(8-9)}$.

\section{Population}

Ten Haitian immigrants participated in the study. Inclusion criteria considered Haitian immigrants who were undergraduate students of a public university in southern Brazil, considering that they could already understand Portuguese. Exclusion criteria considered immigrants with irregular attendance in classes and those who were on a sick leave.

An email was sent to the 92 Haitian immigrants enrolled in the university's undergraduate courses, inviting them to a meeting related to the research, at which 23 were present. However, as they studied at different periods of the day, the availability of 10 immigrants could be accommodated, and they became the study participants.

\section{DATA COlLECTION}

Data collection took place in the second half of 2019, with the completion of three Culture Circles, organized every two weeks with a duration of two hours. An audio recorder was used, with the participants' knowledge and authorization. In addition, records of the topics raised in the Culture Circles were made through fieldnotes.

This article proposed to address the discussions of the third Culture Circle, regarding the possibilities to promote health in the face of immigration vulnerabilities. To go through the steps of the Research Itinerary, an analogy with the construction of a house was chosen, as the house depends on all its structures to remain built, and this was significant for Haitian immigrants. Thus, the researchers organized a puzzle for assembling the house during the Culture Circle, which instigated the dialogue among the participants in a creative and playful way, as shown in Figure 1. 
Paulo Freire's Research Itinerary: analogy with the construction of a house

\section{Codification and Decodification (walls and roof): \\ based on the generating themes, search for their meanings, contextualization and expansion of knowledge in a setting of "awareness".}

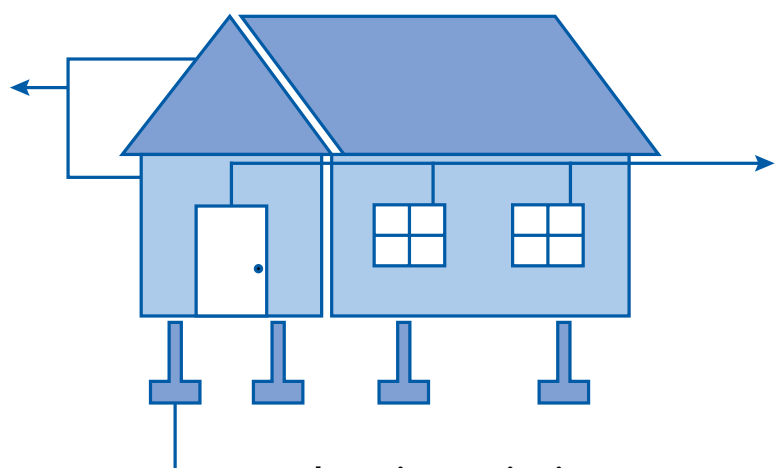

3. Critical Unveiling (doors and windows): analysis of content extracted from codification, representing the reality and possibilities.

1. Thematic Investigation

(basis): themes extracted from the subjects' experiences.

\section{Culture Circle with Haitian immigrants}

Figure 1 - Paulo Freire's Research Itinerary: analogy with the construction of a house.

Thematic Investigation, the first step of the Research Itinerary, aims to stimulate the participants' critical thinking, starting with particular realities, with the emergence of generating themes and their problematization ${ }^{(8)}$. The house fundamentals were considered as the Thematic Investigation, with the three generating themes about the vulnerabilities of immigration that were investigated in the first Culture Circle being transcribed and exposed to the ground, and the participants answered the question: what are the vulnerabilities in the experience of Haitian immigration in Brazil? The themes were re-read and reframed by the participants, and the house construction was initiated.

The second step corresponds to Codification and Decoding, which is the moment when the dialogues about the generating themes instigate an analysis of reality and its contradictions, in which each participant reflects on themselves as capable of transforming their actions, modifying their views of the world ${ }^{(8)}$. For this phase, the house walls and roof were built in discussions mediated by three guiding questions, debated in small groups and then shared, which are: What suggestions to promote Haitian immigrants' health at the university and at work? What suggestions to promote adaptation of Haitian immigrants in Brazil? What suggestions to promote Haitian immigrants' physical and mental health?

The last step of the Research Itinerary is the Critical Unveiling, when the house doors and windows were assembled, reflecting on the reality and the possibilities, sealing the action-reflection-action process, with each participant understanding their own ability to face the challenges raised, sharing proposals for action when thinking ${ }^{(8)}$. At this time, immigrants also addressed the relevance of having participated in the Culture Circle.

\section{Data ANALYSIS AND TREATMENT}

In Paulo Freire's Research Itinerary, as these are interdependent steps, collection and analysis are carried out concurrently. Therefore, during the Culture Circle, data were analyzed in a continuous process, with the involvement of all participants through dialogue and reflection on the themes investigated ${ }^{(9)}$, and the critical interpretation of emerging themes.

\section{ETHICAL ASPECTS}

The research followed the ethical principles of Resolution no. 466/2012, of the National Health Council. To ensure anonymity, the immigrants chose to be identified in the study by names of typical Haitian food. The participants read and signed a Free and Informed Consent Form. The research was started only after being approved by the Research Ethics Committee, with Report no. 3.324.430/19.

\section{RESULTS}

The ten study participants were 21 to 25 years old, eight male and two female, residents of the city of Chapecó, Santa Catarina state, for five months to six years, with one student of Nursing, two of Pedagogy, two of Environmental Engineering, one of Geography, two of Mathematics, and two of Languages and Literature. The reason for the immigration to Brazil was the search for a better life and an opportunity to study.

After extensive discussion in the Culture Circle on the vulnerabilities experienced in immigration, the participants chose three main themes for discussion, as shown in Chart 1, namely: 1) Student and worker; 2) Adaptations to life in Brazil; 3) Physical and mental health. 
Chart 1 - Representation of the three generating themes discussed in the Culture Circle.

\begin{tabular}{|l|l|l|}
\hline 1. Student and worker & 2. Adaptations to life in Brazil & 3.Physical and mental health \\
\hline Lack of time to study & Linguistic difficulty & Lack of healthy food \\
The teacher's role & Lack of acceptance & Lack of time to exercise \\
Lack of integration & Lack of knowledge on their rights & Lack of time for self-care \\
Reconciling work and study & Prejudice & Anguish \\
Hard work & Discrimination & Sadness \\
Discrimination & Lack of empathy & Lack of sincere friendships \\
Prejudice & Difficulty with the weather & Lack of leisure \\
Low income & Missing Haitian food & Lifferent food \\
A lot of responsibility & & Lack integration \\
Lack of equity & & Longing for their family
\end{tabular}

After defining the three themes, the participants discussed the possibilities of promoting health, seeking to overcome their reality reflected in the vulnerability factors they experienced in the migratory process. When discussing the first generating theme, the immigrants shared how they tried to promote their well-being at the university, being proactive and participating in university activities. In addition, they pointed out the need to create spaces to bring immigrants and Brazilians closer:

I have contact with many people because I try to get involved, play football, participate in trips with the class, participate in the student's union. So, I don't stay in my place alone; we, immigrants, have to try to interact and make friends here (Pitimi).

Participating in extension projects at the university because you meet new people... it's a matter of us leaving our place and moving around (Lambi).

More moments to bring Brazilians and immigrants together should be organized, so that there is an exchange of experiences because one can always learn from the other here at the university (Akamil).

Within the university space, the role of the professor as an agent promoting the inclusion of immigrants was highlighted:

The teacher is essential here at the university to help us have better integration in class (Lalo).

The teacher's role is to seek to integrate these students into the whole class and not to leave Haitians all together in a single group. Teachers have to work on inclusion, they have to understand that there are not only Brazilians in the classroom (Pitimi).

The poor granting of rights to Haitian immigrants in Brazil was evidenced in the statements made about work, a field greatly filled with immigrants in the country; many times the immigrants do not know their rights and are not always provided with the adequate conditions. Yet, they said that they are considered disqualified by different fields of work, having few opportunities, with prejudice being a determinant. Thus, they mentioned the need to know their rights in the country, in search for better living conditions:
Other companies and sectors could make better use of and welcome Haitian immigrants. Why have only the slaughterhouses accepted us? Because it is something that Brazilians do not want, and immigrants are left without other opportunities. I just don't know if it is because we are black or because we are Haitians, or both. This prejudice has to come to an end! (Lambi).

The working immigrant shall have the same rights as Brazilians. Companies should make better use of the workforce and the knowledge and profile of immigrants (Lalo).

We need to know our rights (Griyo).

When talking about the second generating theme, the mastery of the Portuguese language was one of the most cited issues by the participants, being mentioned as a critical requirement to stimulate communication and socialization in the country. Their reports revealed a mutual and voluntary support among themselves, as they help each other in the process of identifying and teaching the language:

When an immigrant speaks Portuguese it is good for them and also for the community where they live, so knowing Portuguese interferes with all health and adaptation in Brazil (Akamil).

You already have many alternatives to learn the language, at the university and also in several neighborhoods. It is good for all immigrants to try to learn (Pitimi).

I teach about 100 Haitians now, for free, and I tell them, that they have to try to understand that they are no longer in Haiti, that they have to do their part to adapt here in Brazil (Pitimi).

Haitian immigrants mentioned the difficulty in understanding Brazilian laws, as they differ from the laws of their country of origin, but they reinforced the need to understand them in order to live with dignity:

Many laws in Brazil are different and we need to know (Pitimi).

Immigrants revealed that there are charitable social sectors that help them adapt to the characteristics of the new country, such as the remarkable winter:

In winter, immigrants have to wear many pieces of clothes to be kept warm, but this is expensive, so they have to seek help getting 
woolen jackets and blouses in churches. Here at the university there is also a sector that helps (Bonyon).

During the discussion of the third generating theme, Haitian immigrants mentioned the lack of healthy food compared to their native food and how this is inherent to the maintenance of quality of life, highlighting some conditions for them considering food healthy:

To promote our healthy cuisine more frequently and those who do not know how to cook can learn from others who know how to cook... (Lambi).

We still need to eat more vegetables, just like in Haiti, I think they are missing in the Brazilian meals ... plenty of vegetables is something that contributes a lot to health (Lalo).

Healthy eating is the one produced with no pesticides. One way out is to try to cultivate them ourselves and try as hard as possible to eat food without these chemicals... (Lambi).

A good diet leads you to do good exercise too, which is important for physical and mental health (Griyo).

Immigrants exposed ideas for physical activities at the university, since many academics study full time and/or work in other shifts, and do not have time to practice self-care:

We could run a project to take physical exercises here at the university, during classes breaks, when people do nothing (Griyo).

Having bicycles at the university for students and teachers to ride during class breaks to relax a little, and the promotion of an integrative gymkhana, such as jumping rope, playing ball; this would also help in mental health, self-care, and the integration of Brazilians and Haitians (Ble).

Another suggestion was the social integration to preserve mental health, in addition to the use of technology to keep in touch with those who stayed in the country of origin, in order to minimize the longing for family members:

Playing, interacting with other people, making new friends, help with depression (Macós).

Going to Haiti is difficult because of the tickets high price, so what we have left to do is to interact by cell phone (Pitimi).

Technology brings many possibilities, such as the creation of a WhatsApp group, making a call via Skype, the family is not here, but we talk almost every day, and this helps handling with homesickness (Lambi).

A significant proposal from the participants was to hold meetings for Haitians, given the perception of the need to create and/or keep bonds, seeking to alleviate sadness, anxiety and homesickness. The participants revealed that they missed having time for leisure and for preserving their native language:

To organize more meetings for Haitians only, so that we will be able to speak a little more our language and in some way, ease the longing for Haiti, and it is a form of leisure and integration for all of us, relieving anxiety and sadness (Ble).
When asked about the importance and significance of the Culture Circles, they expressed gratitude for the moments they experienced that reflected on learning, and the desire to make changes in favor of their health promotion:

These moments here were very good because they made me think of things that I had not worried about. Thanks for the opportunity! (Griyo).

I thank you for the discussions we had because being together, even on this cold day, made us feel good, I felt like within family, it made me think about changing some habits and we should have more moments like this (Lambi).

I want to try to eat better and even with busy time, do exercises and be more concerned about my health (Griyo).

I think I need to take more advantage of the opportunities that the university can offer and try to make new friends here (Pitimi).

A concern of the study participants was that the results of the research were recognized by other people, mainly nonimmigrants, which was evidenced in the reports in which they expressed the intense desire for the reflections discussed to be shared:

I hope that everything we discussed at the meetings leads to many results, that publications come out for more people to reflect on the immigration situation in Brazil (Lambi).

I hope that other people also get to know everything we have discussed here and help to improve the immigrants' health. (Adamil).

During the Culture Circles, the participants were able to express their experiences and reframe vulnerabilities surrounding them, looking for real possibilities to promote their health. All those involved underwent self-reconstruction after the reflections; individually and collectively, in a symbolic way, they were able to open their doors and windows to new knowledge, getting transformed and empowered towards health promotion.

\section{DISCUSSION}

Vulnerability involves individual, collective, and programmatic aspects. The individual ones refer to the degree and quality of individuals' information about the health-disease process. The collective ones involve access to means of communication, schooling, and material resources. The programmatic ones are related to the understanding of policies and institutions, elements influencing vulnerability conditions ${ }^{(10)}$. It can be said that Haitian immigrants are part of the three planes, being a deeply vulnerable public.

The issue of health vulnerability may be associated with the idea of fragility, when the individual's exposure to a situation involving their health and illness conditions is considered.The fact is that vulnerability shall be seen as something dynamic, not as a concept that solidifies reality, but as part of concrete health work processes, as an integral part of a social and political movement ${ }^{(11)}$. Therefore, it is essential to renew the ways health is built, expanding the understanding of individual and collective needs beyond biomedical and epidemiological knowledge. Knowledge involving vulnerability 
and health has its origin in the social and human sciences, encompassing the human being in its entirety ${ }^{(12)}$.

Immigrants experience social changes and losses due to the break of their ties with the native language, family, friends and cultural habits, leading to their identity deconstruction and subsequent reconstruction, outlined by social and cultural relations, and it is relevant to provide collective spaces to bring them closer to the recipient culture. The relationship between Haitian immigrants and Brazilians reveals a social gap, even if only within the university, where immigrants commonly face resistance to their culture and difficulties in creating bonds, which can lead to loneliness and helplessness ${ }^{(1)}$.

Distancing from their nationality triggers physical and psychological suffering, which requires new bonds and adaptation to the new community ${ }^{(13)}$. Leisure activities are options that provide socialization, easing stress and anxiety. These practices are protective elements to reduce longing for family members, friends and culture, structuring a new psychosocial support network for immigrants ${ }^{(14)}$.

The difficulty of integration is related to the lack of knowledge of the Portuguese language and consequent communication barriers. This is associated with the pedagogical support provided to immigrants, who find obstacles in the integration within the teaching spaces, which are even constituted by the production of discrimination and stereotypes, even if hidden. Immigrants' integration relies on factors of public responsibility, but it is also at the mercy of everyone involved with the educational institution ${ }^{(3)}$.

Since the arrival in Brazil, the need for interaction between the Haitian and Brazilian people is seen as immediate, as a factor that will assist in their daily lives regarding studies, work, health and leisure. For this, it is important that immigrants try to understand and speak Portuguese, which is already taught in some environments, such as in companies, churches, and universities ${ }^{(15)}$.

At university settings, the relevance of the teacher as a provider of integration and shared knowledge is highlighted. The teacher-student relationship shall be horizontal in the teaching-learning process, and is considered one of the richest possibilities to carry out dialogues, exchanges of knowledge, and involvement with the conditions and particularities of each one, making the educational act dependent on the social relationship ${ }^{(16)}$.

It is important to highlight that Brazil is in charge of the legal process of legality of immigrant insertion; however, it does not always provide mechanisms for socio-cultural adaptation, keeping immigrants unknowledgeable of their rights and duties. This lack affects their adaptation, occupation, and economic condition. Some institutions play a role in meeting these needs, such as religious institutions, government agencies, and Non-Governmental Organizations (NGOs), helping with housing, food, language teaching, employment and clothing, remedying the immigrants shortcomings ${ }^{(16)}$.

To live in Brazil, immigrants need a source of income, due to the urgency to build life in the new country. The new Law on Migration in Brazil guarantees the same labor rights to the native Brazilians and the immigrants in regular situation, and shall ensure it. However, insertion in the labor market brings to light a reality made up of inequalities, which lacks adherence to the guarantee of basic rights to the immigrant's dignity ${ }^{(17)}$.

Some of the problems they have to face are work overload and poor and unhealthy conditions, as well as the social vulnerabilities. The immigrant already leaves Haiti with financial difficulties, which may reflect on a process of psychic and somatic illness that begins to pose worrying physical limits ${ }^{(1)}$. The participants of this study also addressed racial prejudice and discrimination as factors that negatively influence social inclusion, placing them far from social groups formed by Brazilians ${ }^{(3)}$.

Sociocultural differences between Haiti and Brazil also affect immigrants' health, requiring adaptations to peculiarities, such as winter and food. Food is a health determinant cited by the World Health Organization (WHO) and, due to the lack of income, of food quality, of time to prepare the food, or of knowledge to prepare it, added to the culinary differences cited as difficulties, their food becomes weak, usually not organic, based on what is accessible ${ }^{(18)}$.

The practice of physical activities combined with healthy eating is a way of promoting health, being physically and mentally beneficial. However, in the academic community, where many immigrants are present, it is difficult to practice this reality due to factors associated with socioeconomic conditions and time deprivation ${ }^{(19)}$, and the encouragement of healthy practices in favor of quality of life is required.

Efforts are urgently needed to promote the expanded concept of health for Haitian immigrants, with the adoption of intersectoral actions and community engagement, as a way of reducing social vulnerabilities. The effectiveness of these actions can be achieved through the principles of the modern concept of health promotion, which encourages the emancipation of individuals, to value people's autonomy to transform reality, and diverges from the behaviorist current that believes in changing individual behaviors as a solution to health problems ${ }^{(20)}$. In this perspective, health promotion actions are focused on educational activities related to behavioral threats that can be modified by individuals, such as smoking and physical activities. Therefore, actions should be encouraged to increase the participation of immigrants in controlling the health-disease process, by acting on conditioning factors that can affect health ${ }^{(21)}$, reinforcing their empowerment in the face of social vulnerabilities that they experience in immigration.

Currently, in Brazil and in the world, there are countless challenges inherent in the relationship between immigration and health. As challenges, the social policies of embracement and integration of immigrants in the globalized world stand out, who need to face the situations of socioeconomic inequalities, illness and precarious living conditions. It is essential to promote equity of access to health, expand social policies, and include the theme of migration as social determinants that shall be addressed by professionals in health services ${ }^{(22)}$.

In contrast, the Culture Circle provided a critical reading of the knowledge and practices of Haitian immigrants, promoting action-reflection-action. The construction of the 
house led to the awareness of their life moment, and of the need to overcome challenges, developing self-care and health promotion. This context is also important for health professionals, who have to understand the current demands to ensure the effectiveness of SUS's principles, with an emphasis on universality and equity.

However, there is still a lot to learn and accomplish within care of immigrants, given the vulnerabilities they face in the health-disease process. Thus, interventions that embrace their sufferings are recommended, being up to Nursing and other health professionals to maintain attention to the assistance to this public, who lacks information about their rights in the Brazilian society. Moreover, further studies on the subject are required.

\section{CONCLUSION}

Haitian immigrants cited vulnerabilities related to being a student and a worker, to adaptations in Brazil, and to physical and mental health. The university is one of the spaces to stimulate and promote the Haitian student's health, with some possibilities being: participation in social groups, moments of approximation between Brazilians and Haitians, and the effective role of the teacher in the integration of immigrants in the classroom. They also revealed that it is essential to know their rights and fight for working conditions and opportunities, highlighting that there is still prejudice and discrimination in work activities in southern Brazil.

As for adaptation, they consider it necessary to master the Portuguese language, which interferes in the interaction and sociocultural adaptation in the environments they frequent, and to seek strategies for adapting to the Brazilian cuisine. In terms of physical and mental health, they highlighted the lack of healthy food due to economic difficulties and culinary differences in the two countries, and sports and leisure activities to provide new bonds, suggesting the creation of a psychosocial support network that facilitates the promotion of mental health and provides quality of life.

The construction of the house allowed for a pleasant and playful discussion about vulnerabilities and health promotion in the perspective of immigration, creating a relationship with the current residence of immigrants in Brazil and its repercussions on health for the public under study, which made the theoretical-philosophical thinking by Paulo Freire practical and transformative.

\section{RESUMO}

Objetivo: Compreender as percepções dos imigrantes haitianos sobre as possibilidades para promover a saúde, diante das vulnerabilidades que vivenciam. Método: Estudo qualitativo, do tipo ação-participante, fundamentado no Itinerário de Pesquisa de Paulo Freire, que possui três fases: investigação temática; codificação e descodificação; desvelamento crítico. Participaram do Círculo de Cultura dez imigrantes haitianos, estudantes de uma universidade pública do Brasil. Resultados: Diante das vulnerabilidades, os imigrantes haitianos revelaram a necessidade de participar dos grupos sociais universitários, ter momentos de integração com brasileiros, conhecer seus direitos, ter domínio da língua portuguesa, adaptar-se aos aspectos socioculturais e à culinária, promover a saúde mental e qualidade de vida por meio de atividades físicas e lazer. Conclusão: As discussões possibilitaram o processo de ação-reflexão-ação, em que os imigrantes ressignificaram sua realidade, buscando estratégias para promover saúde e empoderando-se para a busca de uma vida mais saudável.

\section{DESCRITORES}

Imigração; Vulnerabilidade; Promoção da Saúde; Equidade em Saúde; Qualidade de Vida; Enfermagem em Saúde Pública.

\section{RESUMEN}

Objetivo: Comprender las percepciones de los inmigrantes haitianos sobre las posibilidades de promover la salud, frente a las vulnerabilidades que enfrentan. Método: Estudio cualitativo, de tipo acción-participante, fundamentado en el Itinerario de Investigación de Paulo Freire, que comprende tres fases: investigación temática; codificación y descodificación; y exposición crítica. Participaron en el Círculo de Cultura diez inmigrantes haitianos, estudiantes en una universidad pública de Brasil. Resultados: Frente a las vulnerabilidades, los inmigrantes haitianos revelaron la necesidad de participar en los grupos sociales universitarios, de tener momentos de integración con los brasileños, de conocer sus derechos, de dominar la lengua portuguesa, de adaptación sociocultural y culinaria, de promoción de la salud mental y de calidad de vida a través de actividades físicas y de ocio. Conclusión: Las discusiones permitieron el proceso de acción-reflexión-acción, en el cual los inmigrantes resignificaron su realidad, buscando estrategias para promover la salud y empoderándose para la búsqueda de una vida más sana.

\section{DESCRIPTORES}

Inmigración; Vulnerabilidad; Promoción de la Salud; Equidad en Salud; Calidad de Vida; Enfermería en Salud Pública.

\section{REFERENCES}

1. Gomes MA. Os impactos subjetivos dos fluxos migratórios: os haitianos em Florianópolis (SC). Psicol Soc. 2017;29:e162484. doi: https:// doi.org/10.1590/1807-0310/2017v29162484

2. Lima SS, Silva LMM. Os imigrantes no Brasil, sua vulnerabilidade e o princípio da igualdade. Rev Bras Políticas Públicas. 2017;7(2):384403. doi: https://doi.org/10.5102/rbpp.v7i2.4804.

3. Oviedo RAM, Czeresnia D. O conceito de vulnerabilidade e seu caráter biossocial. Interface (Botucatu) 2015;19(53):237-50. doi: org/10.1590/1807-57622014.0436.

4. Souza JB, Heidemann ITSB, Walker F, Schleicher ML, Campagnoni JP. Reflexões sobre saúde com imigrantes haitianos pelo Itinerário de Pesquisa de Paulo Freire. Rev Eletr Enferm. 2020;22:e60792. doi: https://doi.org/10.5216/ree.v22.60792

5. World Health Organization. The Ottawa Charter for Health Promotion [Internet]. Ottawa; 1986 [cited 2019 Sept 20]. Available from: https://www.who.int/teams/health-promotion/enhanced-wellbeing/first-global-conference 
6. Owusu-Addo E, Smith BJ. Cash transfers and the social determinants of health: a conceptual framework. Health Promot Int. 2019;34(6):e10618. doi: 10.1093/heapro/day079

7. Felcher CDO, Ferreira ALA, Folmer V. Da pesquisa-ação à pesquisa participante: discussões a partir de uma investigação desenvolvida no facebook. Exper Ensino Ciênc [Internet]. 2017 [citado 2020 set. 03];12(7):1-18. Disponível em: http://if.ufmt.br/eenci/artigos/Artigo_ID419/ v12_n7_a2017.pdf

8. Heidemann ITSB, Dalmolin IS, Rumor PCF, Cypriano CC, Costa MFBNA, Durand MK. Reflexões sobre o itinerário de pesquisa de Paulo Freire: contribuições para a saúde. Rev. Texto Contexto Enferm. 2017;26(4):e0680017. doi: http://dx.doi.org/10.1590/010407072017000680017

9. Garzon AMM, Silva KL, Marques RC. Liberating critical pedagogy of Paulo Freire in the scientific production of Nursing 1990-2017. Rev Bras Enferm. 2018;71 Suppl 4:1751-8. doi: http://dx.doi.org/10.1590/0034-7167-2017-0699.

10. Ayres JR, Paiva V, França JRI. Vulnerabilidade e direitos humanos. Curitiba: Juruá; 2012.

11. Ayres JR, Castellanos MEP, Baptista TWF. Entrevista com José Ricardo Ayres. Saúde Soc. 2018;27(1):51-60. doi: https://doi.org/10.1590/ s0104-12902018000002

12. Calazans, GJ, Pinheiro TF, Ayres JRCM. Vulnerabilidade programática e cuidado público: Panorama das políticas de prevenção do HIV e da Aids voltadas para gays e outros HSH no Brasil. Sex Salud Soc (Rio J.). 2018;29:263-93. doi: https://doi.org/10.1590/1984-6487. sess.2018.29.13.a

13. Oliveira EN, Monteiro Neto FF, Freire AS, Félix TA, Moreira RMM, Lima GF. Saúde de imigrantes: estudo baseado em evidências. SANARE. 2016;15(1):74-81.

14. Melo JO, Romani PF. Resiliência de imigrantes haitianos frente ao processo de adaptação no novo país: impactos na saúde mental. Psicol Argum. 2019;37(96):184-206. doi: http://dx.doi.org/10.7213/psicolargum.37.96.AO03

15. Silva FR, Fernandes D. Desafios enfrentados pelos imigrantes no processo de integração social na sociedade brasileira. Rev Inst Ciênc Human. 2017;13(18):50-64.

16. Lopes BD, Andrade FB, Chaves NPS. A aula universitária: onde ficam professor e aluno? Ensino Re-Vista. 2016;23(1):90-110. doi: https:// doi.org/10.14393/ER-v23n1a2016-5

17. Silva MA, Mandalozzo Neto SS, Silva LAM. Migrações e trabalho: uma análise a partir dos direitos sociais fundamentais. Rev Eletr Trib Reg Trab 9ª Região [Internet]. 2018 [citado 2019 out. 7];7(68):53-60. Disponível em: https://hdl.handle.net/20.500.12178/142133

18. Granada D, Carreno I, Ramos N, Ramos MCP. Discutir saúde e imigração no contexto atual de intensa mobilidade humana. Interface (Botucatu). 2017;21(61):285-96. doi: https://doi.org/10.1590/1807-57622016.0626

19. Moura IH, RS Nobre, Cortez RMA, Campelo V, Macedo SF, Silva ARV. Qualidade de vida de estudantes de graduação em enfermagem. Rev Gaúcha Enferm. 2016;37(2):e55291. doi: http://dx.doi.org/10.1590/1983-1447.2016.02.55291

20. Heidemann, ITSB, Cypriano CC, Gastaldo D, Jackson S, Rocha CG, Fagundes E. Estudo comparativo de práticas de promoção da Saúde na Atenção Primária em Florianópolis, Santa Catarina, Brasil e Toronto, Ontário, Canadá. Cad Saúde Pública. 2018;34(4):e00214516. doi: https://doi.org/10.1590/0102-311X00214516.

21. Malta DC, Silva MMA, Albuquerque GM, Lima CM, Cavalcante T, Jaime PC et al. A implementação das prioridades da Política Nacional de Promoção da Saúde, um balanço, 2006 a 2014. Ciênc Saúde Coletiva. 2014;19(11):4301-12. doi: https://doi.org/10.1590/1413812320141911.07732014

22. Granada D, Carreno I, Ramos N, Ramos MCP. Discutir saúde e imigração no contexto atual de intensa mobilidade humana. Interface (Botucatu). 2017;21(61)]:285-96. doi: https://doi.org/10.1590/1807-57622016.0626 